\title{
Nucleophilic substitution-cyclization based fluorescent probes for hydrogen sulfide detection and bioimaging
}

\author{
Bo Peng ${ }^{[a],+}$, Wei Chen ${ }^{[a]},+$, Chunrong Liu ${ }^{[a]}$, Ethan W. Rosser ${ }^{[a]}$, Armando Pacheco ${ }^{[a]}$, Yu \\ Zhao $^{[a]}$, Hector C. Aguilar ${ }^{[b]}$, and Ming Xian ${ }^{[a]}$ \\ Ming Xian:mxian@wsu.edu \\ ${ }^{[a] D e p a r t m e n t ~ o f ~ C h e m i s t r y, ~ W a s h i n g t o n ~ S t a t e ~ U n i v e r s i t y, ~ P u l l m a n, ~ W A ~ 99164, ~ U S A ~}$ \\ [b]Paul G. Allen School for Global Animal Health, Washington State University, Pullman, WA \\ 99164, USA
}

\begin{abstract}
The design, synthesis, properties, and cell imaging applications of a series of pyridine-disulfide based fluorescent probes (WSP1, WSP2, WSP3, WSP4 and WSP5) for hydrogen sulfide detection are reported. The strategy is based on the dual-nucleophilicity of hydrogen sulfide. A hydrogen sulfide mediated tandem nucleophilic substitution-cyclization reaction is used to release the fluorophores and turn on the fluorescence. The probes showed high sensitivity and selectivity for hydrogen sulfide over other reactive sulfur species including cysteine and glutathione.
\end{abstract}

\section{Keywords}

fluorescent probes; hydrogen sulfide; cell imaging; cyclization; fluorescence

\section{Introduction}

Hydrogen sulfide $\left(\mathrm{H}_{2} \mathrm{~S}\right)$, although historically known as a toxic gas, has been recently classified as a critical cell signalling molecule like nitric oxide (NO). ${ }^{[1-6]}$ Literature published in the past few years increasingly suggests that $\mathrm{H}_{2} \mathrm{~S}$ is a mediator of many physiological and/or pathological processes, especially in cardiovascular systems. ${ }^{[1-6]}$ The production of $\mathrm{H}_{2} \mathrm{~S}$ in mammalian systems has been attributed to at least three endogenous enzymes: ${ }^{[5-10]}$ cystathionine $\beta$-synthase, cystathionine $\gamma$-lyase, and 3-mercaptopyruvate sulfur-transferase. These enzymes use cysteine or cysteine derivatives as the substrates and convert them into $\mathrm{H}_{2} \mathrm{~S}$ within different organs and tissues.

To date, $\mathrm{H}_{2} \mathrm{~S}$ 's exact mechanisms of action are still under active investigation. As a highly reactive molecule, $\mathrm{H}_{2} \mathrm{~S}$ is known to react with a number of biological targets and these reactions may be responsible for the biological functions of $\mathrm{H}_{2} \mathrm{~S}$. For example, $\mathrm{H}_{2} \mathrm{~S}$ reacts readily with methemoglobin to form sulfhemoglobin, which might act as a metabolic sink for $\mathrm{H}_{2} \mathrm{~S}$. $\mathrm{H}_{2} \mathrm{~S}$ is a powerful reducing agent likely to react with endogenous oxidants such as

Correspondence to: Ming Xian, mxian@wsu . edu.

十These authors contributed equally to this work. 
peroxynitrite, superoxide and hydrogen peroxide. $\mathrm{H}_{2} \mathrm{~S}$ can also cause protein $S$-sulfhydration (i.e. converting cysteine residues $-\mathrm{SH}$ to persulfides $-\mathrm{S}-\mathrm{SH}$ ). Although the detailed mechanism of $S$-sulfhydration is still unclear this process has been considered as an important posttranslational modification. It provides a possible mechanism by which $\mathrm{H}_{2} \mathrm{~S}$ alters the functions of a wide range of cellular proteins and enzymes. ${ }^{[1-16]}$ It is possible that many more important reactions of $\mathrm{H}_{2} \mathrm{~S}$ are to be discovered. Nevertheless, the production of endogenous $\mathrm{H}_{2} \mathrm{~S}$ and the exogenous administration of $\mathrm{H}_{2} \mathrm{~S}$ have been demonstrated to exert protective effects in many pathologies. ${ }^{[1-8]}$ It is important, therefore, to understand the chemistry and properties of $\mathrm{H}_{2} \mathrm{~S}$ and to develop effective and convenient methods for the detection of $\mathrm{H}_{2} \mathrm{~S}$ in biological systems.

Fluorescence based assays can be very useful in this field due to the high sensitivity and convenience. Fluorescence methods are suitable for non-destructive detection of bio-targets in live cells or tissues with readily available instruments. In 2011 our laboratory and several other groups reported the first reaction-based fluorescent probes for $\mathrm{H}_{2} \mathrm{~S}$ detection. ${ }^{[17-21]}$

These works have inspired many researchers to develop new $\mathrm{H}_{2} \mathrm{~S}$ fluorescent probes and a number of papers have been published in the past two years. ${ }^{[22,23]}$ One of the main challenges for current fluorescent probes is the high selectivity for $\mathrm{H}_{2} \mathrm{~S}$ versus other biothiols. The strategy used in the design of our first generation $\mathrm{H}_{2} \mathrm{~S}$ probe was based on a unique $\mathrm{H}_{2} \mathrm{~S}$-mediated nucleophilic addition followed by an intramolecular cyclization to turn on the fluorescence signals. ${ }^{[18]}$ This method is highly specific for $\mathrm{H}_{2} \mathrm{~S}$. We have expanded this strategy and a series of new probes have been prepared and evaluated. This article is to report the design and synthesis of these probes, the optimization of the detection conditions, as well as the applications of the probes in cell imaging.

\section{Results and Discussion \\ Design and synthesis of probes}

$\mathrm{H}_{2} \mathrm{~S}$ can be considered as a reactive nucleophile in biological systems and it should undergo nucleophilic substitution or addition reactions easily. In order to selectively detect $\mathrm{H}_{2} \mathrm{~S}$ from the biological thiol pool, the key is to differentiate $\mathrm{H}_{2} \mathrm{~S}$ from other biothiols such as cysteine (Cys) and glutathione (GSH). $\mathrm{H}_{2} \mathrm{~S}$ is a non-substituted thiol that can undergo nucleophilic reaction two times; while other thiols like Cys and GSH are mono-substituted thiols which can only pursue nucleophilic reaction one time. Based on this property, we believe that compounds containing dual-electrophilic enters are useful reagents for $\mathrm{H}_{2} \mathrm{~S}$ detection. As shown in Scheme 1, $\mathrm{H}_{2} \mathrm{~S}$ should react with the most electrophilic component of probe $\mathbf{A}$ to form a free SH containing intermediate B1. If another electrophilic reaction center is presented at a suitable position, like the ester group shown in B1, the SH group should undergo a spontaneous cyclization to release the fluorophore and form product $\mathbf{P}$. This strategy not only can capture $\mathrm{H}_{2} \mathrm{~S}$ as a stable and analyzable product $\mathbf{P}$, but also allows visualizing $\mathrm{H}_{2} \mathrm{~S}$ signals via convenient and sensitive fluorescence measurements. It should be noted that substrate $\mathbf{A}$ may also react with biothiols (RSH). However, product $\mathbf{B} 2$ should not undergo the cyclization to release the fluorophore. In addition, if appropriate electrophiles are employed, it is possible for the first reaction with biothiols to be reversible or non-productive so that the probes won't be consumed by biothiols. Another advantage of 
this strategy is that we can easily modify the structures of all three subunits of the template (electrophile, linker, and fluorophore). Therefore a large library of probes can be prepared and tested. This has great potential to produce ideal fluorescent probes with optimized properties.

To test this idea, we first prepared a model compound $\mathbf{1}$ and tried the reaction with $\mathrm{H}_{2} \mathrm{~S}$ (using NaHS as the equivalent in a buffer system, Scheme 2). In this model compound we envisioned $S$-pyridium disulfide was an effective electrophile for trapping $\mathrm{H}_{2} \mathrm{~S}$ and benzene was an appropriate linker. The rigidity of benzene 1,2-substitutions should facilitate the proposed intramolecular cyclization. As expected, the reaction went well and the desired cyclization product 2 and phenol were obtained in good yield (83\%).

Based on the structure of the model compound, we believed the introduction of pseudofluorophores through the ester linkage should result in selective fluorescent probes for $\mathrm{H}_{2} \mathrm{~S}$. Therefore a series of probes were synthesized (shown in Scheme 3). The common intermediate, 2-(2-pyridinyldithio)-benzoic acid $\mathbf{3}$, was readily prepared from a mixdisulfide formation between 2-mercaptobenzoic acid and 2, 2'-dipyridinyl disulfide. Compound 3 was then coupled with -OH containing fluorophores to give the probes WSP1-5 (Washington State Probes). We chose methoxy fluorescein, 7-hydroxycoumarin, resorufin, and 2-methyl TokyoGreen as the fluorophores because of their readily availability, excellent fluorescence properties, and easy fluorescence quenching via hydroxyl substitution. ${ }^{[24]}$ For WSP5, two reaction centers were introduced to the core structure of fluorescein. Upon reaction with $\mathrm{H}_{2} \mathrm{~S}$, it should produce highly fluorescent species.

\section{Fluorescence properties and responses of probes WSP1-5 to $\mathrm{H}_{2} \mathrm{~S}$}

With these probes in hand, we tested their fluorescent properties. As expected, these probes exhibited very weak fluorescence with low quantum yields $\left(\Phi_{\mathrm{f}}<0.1\right.$, as shown in Table 1) due to the esterification of the hydroxyl group of fluorophores. This low background fluorescence is critical for highly sensitive detection of $\mathrm{H}_{2} \mathrm{~S}$.

We then tested their fluorescence responses to $\mathrm{H}_{2} \mathrm{~S}$ and optimized the fluorescence measurement conditions. WSP1 was used as the representative in these studies. As shown in Figure 1, the fluorescence intensity of WSP1 increased dramatically when $\mathrm{H}_{2} \mathrm{~S}$ was present in the solution. We also found that media plays an important role in this process. When a mixed $\mathrm{CH}_{3} \mathrm{CN} / \mathrm{PBS}$ buffer $(10 \mathrm{mM}, \mathrm{pH} 7.4,1: 1$, v/v) solution was used (due to poor water solubility of the probe), the fluorescence turn-on rate was somewhat slow. The intensity could reach the maximum in about 30 min (36 fold increase). However, when a small amount of surfactant hexadecyltrimethylammonium bromide (CTAB) was added into detection system, the turn on rate was significantly increased and the fluorescence intensity was also significantly enhanced (110-fold). The effects of CTAB may be attributed to 1) CTAB can increase the solubility of the probe in aqueous buffers; and 2) CTAB is a cationic surfactant, which may absorb sulfide anion $\left(\mathrm{HS}^{-}\right)$and facilitate the reaction between sulfide anion and the probe. These effects were also noted in previous work on fluorescent probes. ${ }^{[25]}$ 
We next applied this optimized condition to other probes. As shown in Figure 2 and 3, all of them (WSP2, WSP3, WSP4, and WSP5) exhibited fast fluorescence turn-on toward $\mathrm{H}_{2} \mathrm{~S}$ and usually the fluorescence signals can reach a steady state in a few minutes, the intensities increased 275-, 68-, 20-, and 60-fold (for WSP2, WSP3, WSP4, and WSP5, respectively). This may be very favorable for fast detection of $\mathrm{H}_{2} \mathrm{~S}$. Upon gradual introduction of $\mathrm{H}_{2} \mathrm{~S}$, the fluorescence intensity at the maximal emission wavelength of the probes increased drastically. As can be seen in Figure S1, good linear relationships were obtained between the fluorescence intensity at the maximal emission wavelength of the probes and different hydrogen sulfide concentrations. The detection limits ${ }^{[26]}$ were determined to be $60,79,47$, 266 and 47 nM for WSP1, WSP2, WSP3, WSP4, and WSP5, respectively (Table 2).

To evaluate the potential applications of the probes in different biological environments, we studied $\mathrm{pH}$ effects for all of the five probes (Figure 4). In general these probes worked well under normal biological pH ranges ( $6 \sim 9)$. However, WSP3 and WSP4 showed increased background fluorescence under $\mathrm{pH} 10$, which might be due to the hydrolysis of the ester linkage under this $\mathrm{pH}$.

We next investigated the probes' selectivity for $\mathrm{H}_{2} \mathrm{~S}$, which is the most important property to justify the effectiveness of the probes. In these experiments, each probe $(10 \mu \mathrm{M})$ was treated with different reactive sulfur species including Cys, GSH, Hcy, $\mathrm{SO}_{3} 2-, \mathrm{S}_{2} \mathrm{O}_{3} 2$ - (all at $200 \mu \mathrm{M})$ under the optimized conditions and fluorescence signals were recorded after mixing for $5 \mathrm{~min}$. As shown in Figure 5, these sulfur-containing species did not lead to any significant fluorescence responses while NaHS $(50 \mu \mathrm{M})$ gave very strong signals for all probes. Therefore all the probes are proved to have good selectivity for $\mathrm{H}_{2} \mathrm{~S}$ over other reactive sulfur species including Cys and GSH. As one can imagine, these disulfide-based probes may also react with biothiols in biological systems. Although such reactions won't turn on fluorescence, it could consume the probes and higher loading of the probes may be needed. This is a potential problem for this type of probes. However we realized that the fluorescence turn-on rates of our probes under the optimized conditions were quite fast (within a few minutes). Therefore it is possible that the probes can give significant fluorescence signals even when $\mathrm{H}_{2} \mathrm{~S}$ co-exists with biothiols. To prove this, a solution of NaHS $(50 \mu \mathrm{M})$ and Cys or GSH $(200 \mu \mathrm{M})$ was prepared and the probe $(10 \mu \mathrm{M})$ was then loaded. Pleasantly we still observed significant fluorescence signals for each probe (Figure 5), although at decreased levels compared to NaHS only. These results suggested that the probes were effective for $\mathrm{H}_{2} \mathrm{~S}$ detection in the presence of biothiols.

After proving the sensitivity and selectivity of this series of probes for $\mathrm{H}_{2} \mathrm{~S}$ in aqueous buffers, we decided to explore their applications in imaging $\mathrm{H}_{2} \mathrm{~S}$ in living cells. WSP4 and WSP5 were selected for this study because of their strong fluorescent intensity observed when treating with $\mathrm{H}_{2} \mathrm{~S}$. Before we conducted cell imagine experiments, we realized that our probes contain the fluorophores through an ester linkage. One concern is that such a linkage may be labile in the presence of cellular esterases. In order to address this question, we tested the stability of the probes (WSP1, WSP4 and WSP5) in the presence of esterase (esterase E-0887, from rabbit liver). As shown in Figure 6, the probes were incubated with the enzyme for $30 \mathrm{~min}$ and no significant fluorescence increase was observed. After that 
NaHS was added into the mixture and a strong fluorescence increase was observed. These results suggested that the probes were stable to esterases.

\section{Living cell imaging studies}

Having demonstrated the stability of the probes, we then used them in monitoring $\mathrm{H}_{2} \mathrm{~S}$ in live cells. In brief, freshly cultured Hela cells were incubated with probe WSP4 for $30 \mathrm{~min}$. Then the cells were washed by medium buffer to remove excess probe and treated with different concentrations of NaHS. As shown in Figure 7, we did not observe significant fluorescent cells when NaHS was absent. However, strong fluorescence in the cells was observed after treating with NaHS for $30 \mathrm{~min}$. Cells treated with $60 \mu \mathrm{M}$ NaHS displayed obviously stronger fluorescence than cells treated with $30 \mu \mathrm{M}$ NaHS. In addition, WSP5 was also tested by using the same protocol and similar results were observed. Thus we concluded that these probes can be used for the detection of $\mathrm{H}_{2} \mathrm{~S}$ in living cells.

To further explore the applications of the probes in $\mathrm{H}_{2} \mathrm{~S}$ study we used them in the evaluation of novel $\mathrm{H}_{2} \mathrm{~S}$ donors. $\mathrm{H}_{2} \mathrm{~S}$ donors are another type of important research tools in this field and our laboratory has recently developed several different controllable $\mathrm{H}_{2} \mathrm{~S}$ donors. ${ }^{[27]}$ Among these the perthiol-based donors are of particularly interest because they have exhibited promising activity against myocardial ischemia-reperfusion injury. ${ }^{[27 a]}$ To monitor $\mathrm{H}_{2} \mathrm{~S}$ generation in cells from this type of donors, we applied our newly developed fluorescent probes. Briefly, Hela cells were first incubated with YZ-4-074, a perthiol-based donor, for 30min. After that, the exo-cellular donor was removed by washing with buffers. The cells were then incubated with WSP4. As shown in Figure 8, donor-treated cells showed much enhanced fluorescent signals compared to vehicle-treated cells. We also applied WSP5 in the same protocol and similar results were observed (Figure S2 in supporting information). These results demonstrated that these probes can be used to evaluate synthetic $\mathrm{H}_{2} \mathrm{~S}$ donor in cells.

\section{Conclusion}

In summary, we reported in this study the development of a series of nucleophilic substitution-cyclization based fluorescent probes for $\mathrm{H}_{2} \mathrm{~S}$. Five probes (WSP1-5) were prepared and evaluated. These probes proved to be selective for $\mathrm{H}_{2} \mathrm{~S}$ over other sulfurcontaining species including Cys and GSH. Moreover, fluorescence 'turn-on' are fast. The efficiencies of these probes were demonstrated in aqueous solution and in cell imaging. Further development of nucleophilic substitution-cyclization based probes and application of these probes in $\mathrm{H}_{2} \mathrm{~S}$ studies are currently ongoing in our laboratory.

\section{Experimental Section}

\section{Synthesis of the probes}

Compound $\mathbf{3}$ was prepared using the protocol described previously ${ }^{[18]}$. General procedure for probes synthesis: to a mixture of compound $\mathbf{3}(262 \mathrm{mg}, 1.0 \mathrm{mmol}), \mathrm{OH}$-containing fluorophore (1.0 mmol), EDC (192 mg, $1.0 \mathrm{mmol})$, and DMAP $(12.2 \mathrm{mg}, 0.1 \mathrm{mmol})$ in a 50 $\mathrm{mL}$ round bottom flask was added dry $\mathrm{CH}_{2} \mathrm{Cl}_{2}(25 \mathrm{~mL})$ at room temperature. The mixture 
was stirred for $12 \mathrm{~h}$. Then solvent was removed under reduced pressure and resulted crude product was purified by fresh column chromatography to provide the desired product.

Compound 1 was obtained as a white solid $(273 \mathrm{mg}, 80.5 \%$ yield $)$. M.p. $113{ }^{\circ} \mathrm{C}-115{ }^{\circ} \mathrm{C} ;{ }^{1} \mathrm{H}$ NMR $\left(300 \mathrm{MHz},\left[\mathrm{D}_{1}\right] \mathrm{CDCl}_{3}, 25^{\circ} \mathrm{C}, \mathrm{TMS}\right) \delta=7.06-7.11\left(\mathrm{~m}, 1 \mathrm{H}, \mathrm{H}_{\mathrm{Ar}}\right), 7.24-7.36(\mathrm{~m}, 4 \mathrm{H}$, $\left.\mathrm{H}_{\mathrm{Ar}}\right), 7.41-7.47\left(\mathrm{~m}, 2 \mathrm{H}, \mathrm{H}_{\mathrm{Ar}}\right), 7.50-7.57\left(\mathrm{~m}, 3 \mathrm{H}, \mathrm{H}_{\mathrm{Ar}}\right), 7.97\left(\mathrm{dd}, J_{1}=8.1 \mathrm{~Hz}, J_{2}=2.4 \mathrm{~Hz}, 1 \mathrm{H}\right.$, $\left.\mathrm{H}_{\mathrm{Ar}}\right), 8.30\left(\mathrm{dd}, J=7.8,1.5 \mathrm{~Hz}, 1 \mathrm{H}, \mathrm{H}_{\mathrm{Ar}}\right), 8.45-8.47\left(\mathrm{~m}, 1 \mathrm{H}, \mathrm{H}_{\mathrm{Ar}}\right) ;{ }^{13} \mathrm{C} \mathrm{NMR}(75 \mathrm{MHz}$, $\mathrm{CDCl}_{3}, 25^{\circ} \mathrm{C}$, TMS) $\delta=119.7,121.0,121.7,125.8,126.0,126.2,126.4,129.8,132.0,133.8$, 137.4, 141.4, 149.6, 150.5, 159.0, 164.9; IR (thin film, $\mathrm{cm}^{-1}$ ) 3999.0, 3072.0, 3041.0, 1707.0, 1562.5; MS (ESI) [M+Na] $]^{+}$calcd for $\mathrm{C}_{18} \mathrm{H}_{13} \mathrm{NO}_{2} \mathrm{~S}_{2} \mathrm{Na}$, 362.0; found, 362.0; HRMS $[\mathrm{M}+\mathrm{H}]^{+}$calcd for $\mathrm{C}_{18} \mathrm{H}_{14} \mathrm{NO}_{2} \mathrm{~S}_{2}, 340.0466$; found, 340.0468 .

WSP1: Data was the same as previously reported. ${ }^{[18]}$

WSP2 was obtained as a white solid $\left(374 \mathrm{mg}, 92 \%\right.$ yield). M.p. $165{ }^{\circ} \mathrm{C}-167{ }^{\circ} \mathrm{C} ;{ }^{1} \mathrm{H}$ NMR $\left(300 \mathrm{MHz},\left[\mathrm{D}_{1}\right] \mathrm{CDCl}_{3}, 25^{\circ} \mathrm{C}, \mathrm{TMS}\right) \delta=6.44\left(\mathrm{~d}, J=9.3 \mathrm{~Hz}, 1 \mathrm{H}, \mathrm{H}_{\mathrm{Ar}}\right), 7.09-7.14(\mathrm{~m}, 1 \mathrm{H}$, $\left.\mathrm{H}_{\mathrm{Ar}}\right), 7.23\left(\mathrm{~d}, J=2.1 \mathrm{~Hz}, 1 \mathrm{H}, \mathrm{H}_{\mathrm{Ar}}\right), 7.28-7.29\left(\mathrm{~m}, 1 \mathrm{H}, \mathrm{H}_{\mathrm{Ar}}\right), 7.34-7.39\left(\mathrm{~m}, 1 \mathrm{H}, \mathrm{H}_{\mathrm{Ar}}\right), 7.52-$ $7.61\left(\mathrm{~m}, 4 \mathrm{H}, \mathrm{H}_{\mathrm{Ar}}\right), 7.74\left(\mathrm{~d}, J=9.9 \mathrm{~Hz}, 1 \mathrm{H}, \mathrm{H}_{\mathrm{Ar}}\right), 7.99-8.01\left(\mathrm{~m}, 1 \mathrm{H}, \mathrm{H}_{\mathrm{Ar}}\right), 8.31\left(\mathrm{dd}, J_{1}=7.8\right.$ $\left.\mathrm{Hz}, J_{2}=1.2 \mathrm{~Hz}, 1 \mathrm{H}, \mathrm{H}_{\mathrm{Ar}}\right), 8.48\left(\mathrm{dd}, J=4.2,0.9 \mathrm{~Hz}, 1 \mathrm{H}, \mathrm{H}_{\mathrm{Ar}}\right) ;{ }^{13} \mathrm{C} \mathrm{NMR}\left(75 \mathrm{MHz}, \mathrm{CDCl}_{3}, 25\right.$ ${ }^{\circ} \mathrm{C}$, TMS) $\delta=110.9,116.5,117.2,118.8,120.0,121.4,125.8,126.2,126.5,129.0,132.4$, $134.5,137.6,142.2,143.1,149.9,153.3,155.0,158.9,160.5,164.4$; IR (thin film, $\mathrm{cm}^{-1}$ ) 3098.6, 3064.4, 3034.0, 1733.6, 1707.0; MS (ESI) $[2 \mathrm{M}+\mathrm{Na}]^{+}$calcd for $\mathrm{C}_{42} \mathrm{H}_{26} \mathrm{~N}_{2} \mathrm{O}_{8} \mathrm{~S}_{4} \mathrm{Na}$, 837.0; found, 836.7; HRMS [M+H] ${ }^{+}$calcd for $\mathrm{C}_{21} \mathrm{H}_{14} \mathrm{NO}_{4} \mathrm{~S}_{2}$, 408.0364; found, 408.0362 .

WSP3 was obtained as an orange solid (266 mg, 58\% yield). M.p. $139{ }^{\circ} \mathrm{C}-141{ }^{\circ} \mathrm{C} ;{ }^{1} \mathrm{H}$ NMR $\left(300 \mathrm{MHz},\left[\mathrm{D}_{1}\right] \mathrm{CDCl}_{3}, 25^{\circ} \mathrm{C}\right.$, TMS) $\delta=6.37\left(\mathrm{~d}, J=1.8 \mathrm{~Hz}, 1 \mathrm{H}, \mathrm{H}_{\mathrm{Ar}}\right), 6.90\left(\mathrm{dd}, J_{1}=9.6\right.$, $\left.J_{2}=1.8 \mathrm{~Hz}, 1 \mathrm{H}, \mathrm{H}_{\mathrm{Ar}}\right), 7.11-7.15\left(\mathrm{~m}, 1 \mathrm{H}, \mathrm{H}_{\mathrm{Ar}}\right), 7.31-7.41\left(\mathrm{~m}, 3 \mathrm{H}, \mathrm{H}_{\mathrm{Ar}}\right), 7.48(\mathrm{~d}, J=9.9 \mathrm{~Hz}$, $\left.1 \mathrm{H}, \mathrm{H}_{\mathrm{Ar}}\right), 7.54-7.63\left(\mathrm{~m}, 3 \mathrm{H}, \mathrm{H}_{\mathrm{Ar}}\right), 7.89\left(\mathrm{~d}, J=8.1 \mathrm{~Hz}, 1 \mathrm{H}, \mathrm{H}_{\mathrm{Ar}}\right), 8.02\left(\mathrm{~d}, J=7.5 \mathrm{~Hz}, 1 \mathrm{H}, \mathrm{H}_{\mathrm{Ar}}\right)$, $8.32\left(\mathrm{dd}, J_{1}=7.8 \mathrm{~Hz}, J_{2}=0.9 \mathrm{~Hz}, 1 \mathrm{H}, \mathrm{H}_{\mathrm{Ar}}\right), 8.50\left(\mathrm{~d}, J=3.9 \mathrm{~Hz}, 1 \mathrm{H}, \mathrm{H}_{\mathrm{Ar}}\right) ;{ }^{13} \mathrm{C}$ NMR $(75 \mathrm{MHz}$, $\mathrm{CDCl}_{3}, 25^{\circ} \mathrm{C}$, TMS) $\delta=107.2,109.9,119.4,119.9,121.2,125.4,126.0,126.3,131.2,131.4$, 132.1, 134.3, 134.8, 135.2, 137.5, 141.9, 144.4, 148.4, 149.2, 149.5, 153.2, 158.5, 163.9, 186.2; IR (thin film, $\mathrm{cm}^{-1}$ ) 3100.1, 3064.4, 3040.6, 1704.4, 1624.0; MS (ESI) [2M+Na] ${ }^{+}$ calcd for $\mathrm{C}_{48} \mathrm{H}_{28} \mathrm{~N}_{4} \mathrm{O}_{8} \mathrm{~S}_{4} \mathrm{Na}$, 939.1; found, 938.8; HRMS [M+H] ${ }^{+}$calcd for $\mathrm{C}_{24} \mathrm{H}_{15} \mathrm{~N}_{2} \mathrm{O}_{4} \mathrm{~S}_{2}$, 459.0473; found, 459.0487.

WSP4 was obtained as an orange solid (301mg, 55\% yield). M.p. $114{ }^{\circ} \mathrm{C}-117{ }^{\circ} \mathrm{C} ;{ }^{1} \mathrm{H}$ NMR (300 MHz, $\left.\left[\mathrm{D}_{1}\right] \mathrm{CDCl}_{3}, 25^{\circ} \mathrm{C}, \mathrm{TMS}\right) \delta=2.12\left(\mathrm{~s}, 3 \mathrm{H} ; \mathrm{CH}_{3}\right), 6.47\left(\mathrm{~d}, J=1.8 \mathrm{~Hz}, 1 \mathrm{H}, \mathrm{H}_{\mathrm{Ar}}\right), 6.60$ $\left(\mathrm{dd}, J_{1}=9.9 \mathrm{~Hz}, \mathrm{~J}_{2}=1.8 \mathrm{~Hz}, 1 \mathrm{H}, \mathrm{H}_{\mathrm{Ar}}\right), 6.99\left(\mathrm{~d}, J=9.9 \mathrm{~Hz}, 1 \mathrm{H}, \mathrm{H}_{\mathrm{Ar}}\right), 7.10-7.14\left(\mathrm{~m}, 3 \mathrm{H}, \mathrm{H}_{\mathrm{Ar}}\right)$, 7.19-7.21 (m, 1H, $\left.\mathrm{H}_{\mathrm{Ar}}\right), 7.34-7.47\left(\mathrm{~m}, 4 \mathrm{H}, \mathrm{H}_{\mathrm{Ar}}\right), 7.50\left(\mathrm{~d}, J=8.4 \mathrm{~Hz}, 1 \mathrm{H}, \mathrm{H}_{\mathrm{Ar}}\right), 7.54-7.62$ $\left(\mathrm{m}, 3 \mathrm{H}, \mathrm{H}_{\mathrm{Ar}}\right), 8.00\left(\mathrm{~d}, J=8.1 \mathrm{~Hz}, 1 \mathrm{H}, \mathrm{H}_{\mathrm{Ar}}\right), 8.30\left(\mathrm{dd}, J_{1}=7.8 \mathrm{~Hz}, J_{2}=1.8 \mathrm{~Hz}, 1 \mathrm{H}, \mathrm{H}_{\mathrm{Ar}}\right), 8.47-$ $8.50\left(\mathrm{~m}, 1 \mathrm{H}, \mathrm{H}_{\mathrm{Ar}}\right) ;{ }^{13} \mathrm{C} \mathrm{NMR}\left(75 \mathrm{MHz}, \mathrm{CDCl}_{3}, 25^{\circ} \mathrm{C}\right.$, TMS $) \delta=19.6\left(\mathrm{~s} ; \mathrm{CH}_{3}\right), 106.1,110.4$, 118.4, 118.6, 119.6, 120.4, 121.0, 125.3, 125.9, 126.1, 126.2, 129.0, 129.1, 129.6, 130.5, 130.6, 130.9, 131.9, 132.0, 134.2, 136.1, 137.3, 141.9, 148.0, 149.6, 153.0, 154.0, 158.4, 158.4, 163.8, 185.8; IR (thin film, $\mathrm{cm}^{-1}$ ) 3053.0, 2946.6, 2916.1, 1726.0, 1596.7; MS (ESI) $[2 \mathrm{M}+\mathrm{Na}]^{+}$calcd for $\mathrm{C}_{64} \mathrm{H}_{42} \mathrm{~N}_{2} \mathrm{O}_{8} \mathrm{~S}_{4} \mathrm{Na}, 1117.2$; found, 1116.9; HRMS [M+H] ${ }^{+}$calcd for $\mathrm{C}_{32} \mathrm{H}_{22} \mathrm{NO}_{4} \mathrm{~S}_{2}, 548.0990$; found, 548.0974. 
WSP5 was obtained as a light yellow solid (370 mg, 45\% yield). M.p. $125^{\circ} \mathrm{C}-128{ }^{\circ} \mathrm{C} ;{ }^{1} \mathrm{H}$ NMR $\left(300 \mathrm{MHz},\left[\mathrm{D}_{1}\right] \mathrm{CDCl}_{3}, 25^{\circ} \mathrm{C}, \mathrm{TMS}\right) \delta=6.92-6.95\left(\mathrm{~m}, 2 \mathrm{H}, \mathrm{H}_{\mathrm{Ar}}\right), 7.00-7.03(\mathrm{~m}, 2 \mathrm{H}$, $\left.\mathrm{H}_{\mathrm{Ar}}\right), 7.10-7.12\left(\mathrm{~m}, 2 \mathrm{H}, \mathrm{H}_{\mathrm{Ar}}\right), 7.23-7.38\left(\mathrm{~m}, 5 \mathrm{H}, \mathrm{H}_{\mathrm{Ar}}\right), 7.52-7.61\left(\mathrm{~m}, 6 \mathrm{H}, \mathrm{H}_{\mathrm{Ar}}\right), 7.64-7.75$ $\left(\mathrm{m}, 2 \mathrm{H}, \mathrm{H}_{\mathrm{Ar}}\right), 7.99\left(\mathrm{~d}, J=7.8 \mathrm{~Hz}, 2 \mathrm{H}, \mathrm{H}_{\mathrm{Ar}}\right), 8.07\left(\mathrm{~d}, J=7.2 \mathrm{~Hz}, 1 \mathrm{H}, \mathrm{H}_{\mathrm{Ar}}\right), 8.30(\mathrm{~d}, J=7.2 \mathrm{~Hz}$, $\left.2 \mathrm{H}, \mathrm{H}_{\mathrm{Ar}}\right), 8.47\left(\mathrm{~d}, J=4.2 \mathrm{~Hz}, 2 \mathrm{H}, \mathrm{H}_{\mathrm{Ar}}\right) ;{ }^{13} \mathrm{C}$ NMR $\left(75 \mathrm{MHz}, \mathrm{CDCl}_{3}, 25^{\circ} \mathrm{C}, \mathrm{TMS}\right) \delta 81.6$, 110.7, 116.8, 118.0, 119.8, 121.1, 124.1, 125.3, 125.8, 126.0, 126.2, 129.2, 130.2, 132.1, 134.1, 135.4, 137.4, 141.8, 149.6, 151.6, 151.9, 153.0, 158.8, 164.3, 169.2; IR (thin film, $\mathrm{cm}^{-1}$ ) 3060.6, 2954.2, 2923.7, 1771.6, 1718.4; MS (ESI) [M+Na] ${ }^{+}$calcd for $\mathrm{C}_{44} \mathrm{H}_{26} \mathrm{~N}_{2} \mathrm{O}_{7} \mathrm{~S}_{4} \mathrm{Na}$, 845.1; found, 845.1; HRMS [M+H] $]^{+}$calcd for $\mathrm{C}_{44} \mathrm{H}_{27} \mathrm{~N}_{2} \mathrm{O}_{7} \mathrm{~S}_{4}$, 823.0701; found, 823.0714.

\section{General procedure for $\mathrm{H}_{2} \mathrm{~S}$ determination}

Unless otherwise noted, all the measurements were carried out at room temperature for 5 min in $10 \mathrm{mM}$ PBS buffer (pH 7.4) containing $1 \mathrm{mM} \mathrm{CTAB}$ according to the following procedure: in a test tube, $3.5 \mathrm{~mL}$ of $10 \mathrm{mM}$ PBS buffer (pH 7.4) and $40 \mu \mathrm{L}$ of the stock solution of CTAB were mixed. To this mixture was then added $16 \mu \mathrm{L}$ of the stock solution of the probe. The resulting solution was well-mixed, followed by the addition of the requisite volume of testing species solution. The final volume of the solution was adjusted to $4 \mathrm{~mL}$ with $10 \mathrm{mM}$ PBS buffer ( $\mathrm{pH}$ 7.4). After mixing and standing for $5 \mathrm{~min}$ at room temperature, $3 \mathrm{~mL}$ of the solution was transferred into a $1 \mathrm{~cm}$ quartz cell and fluorescence signal was recorded.

\section{Cell imaging experiments with $\mathrm{H}_{2} \mathrm{~S}$}

Hela cells were cultured in Dulbecco's modified Eagle's Medium (DMEM, Cellgro company) supplemented with $10 \%$ fetal bovine serum, $4 \mathrm{mM}$ glutamine, $100 \mathrm{IU} / \mathrm{mL}$ penicillin, and $100 \mathrm{ug} / \mathrm{mL}$ streptomycin at $37{ }^{\circ} \mathrm{C}$ and with $5 \% \mathrm{CO}_{2}$ for two days. One day before imaging, cells were transferred to 24-well plates. Before use, the adherent cells were washed one time with FBS-free DMEM. For intracellular $\mathrm{H}_{2} \mathrm{~S}$ imaging, the cells were incubated with the probe in FBS-free DMEM at $37{ }^{\circ} \mathrm{C}$ for $30 \mathrm{~min}$. After removal of excess probe and washed with PBS (pH 7.4), the cells were incubated with NaHS for $30 \mathrm{~min}$ in PBS buffer ( $\mathrm{pH} 7.4$, containing $100 \mu \mathrm{M}$ CTAB). Cell imaging was carried out after washing the cells three times with PBS (pH 7.4). All microscopy images were taken on a fluorescence microscope with excitation at $490 \mathrm{~nm}$ (green channel).

\section{Cell imaging experiments with $\mathrm{H}_{2} \mathrm{~S}$ donor}

Medium was removed from the cell plate. The cells were washed by FBS free medium once before they were incubated with or without the donor in FBS free medium. After $30 \mathrm{~min}$, the medium was removed and the cells were washed by FBS free medium. Then the cells were incubated in FBS free medium with the probe (containing $100 \mu \mathrm{M} \mathrm{CTAB}$ ) for $30 \mathrm{~min}$. After washing by PBS twice, the cells were ready for imaging. Fluorescence imaging was performed with fluorescence microscope with GFP light cube for fluorescence channel and $40 \times$ objectives. 


\section{Supplementary Material}

Refer to Web version on PubMed Central for supplementary material.

\section{Acknowledgments}

This work is supported by an American Chemical Society-Teva USA Scholar Grant and NIH (R01GM088226). We thank Prof. Viveka Vadyvaloo for providing the fluorescence microscope for this work.

\section{References}

1. Li L, Rose P, Moore PK. Annu Rev Pharmacol Toxicol. 2011; 51:169-187. [PubMed: 21210746]

2. Szabo C. Nat Rev Drug Disco. 2007; 6:917-935.

3. Wang R. Physiol Rev. 2012; 92:791-896. [PubMed: 22535897]

4. Fukuto JM, Carrington SJ, Tantillo DJ, Harrison JG, Ignarro LJ, Freeman BA, Chen A, Wink DA. Chem Res Toxicol. 2012; 25:769-793. [PubMed: 22263838]

5. a) Kimura H. Amino Acids. 2011; 41:113-121. [PubMed: 20191298] b) Kimura H, Shibuya N, Kimura Y. Antioxid Redox Signal. 2012; 17:45-57. [PubMed: 22229673]

6. Olson KR. Antioxid Redox Signal. 2012; 17:32-44. [PubMed: 22074253]

7. a) Qu K, Lee SW, Bian JS, Low CM, Wong PTH. Neurochem Int. 2008; 52:155-165. [PubMed: 17629356] b) Predmore BL, Lefer DJ, Gojon G. Antioxid Redox Signal. 2012; 17:119-140. [PubMed: 22432697]

8. Whiteman M, Moore PK. J Cell Mol Med. 2009; 13:488-507. [PubMed: 19374684]

9. Stipanuk MH, Ueki I. J Inherit Metab Dis. 2011; 34:17-32. [PubMed: 20162368]

10. Jacob C, Anwar A, Burkholz T. Planta Med. 2008; 74:1580-1592. [PubMed: 18937169]

11. Mustafa AK, Gadalla MM, Sen N, Kim S, Mu W, Gazi SK, Barrow RK, Yang G, Wang R, Snyder SH. Sci Signal. 2009; 2:ra72. [PubMed: 19903941]

12. Sen N, Paul BD, Gadalla MM, Mustafa AK, Sen T, Xu R, Kim S, Snyder SH. Mol Cell. 2012; 45:13-24. [PubMed: 22244329]

13. Yang G, Zhao K, Ju Y, Mani S, Cao Q, Puukila S, Khaper N, Wu L, Wang R. Antioxid Redox Signal. 2013; 18:1906-1919. [PubMed: 23176571]

14. Krishnan N, Fu C, Pappin DJ, Tonks NK. Sci Signal. 2011; 4:ra86. [PubMed: 22169477]

15. Pan J, Carroll KS. ACS Chem Biol. 2013; 8:1110-1116. [PubMed: 23557648]

16. Francoleon NE, Carrington SJ, Fukuto JM. Arch Biochem Biophys. 2011; 516:146-153. [PubMed: 22001739]

17. Lippert AR, New EJ, Chang CJ. J Am Chem Soc. 2011; 133:10078-10080. [PubMed: 21671682]

18. Liu C, Pan J, Li S, Zhao Y, Wu LY, Berkman CE, Whorton AR, Xian M. Angew Chem. 2011; 123:10511-10513.Angew Chem Int Ed. 2011; 50:10327-10329.

19. Peng H, Cheng Y, Dai C, King AL, Predmore BL, Lefer DJ, Wang B. Angew Chem. 2011; 123:9846-9849.Angew Chem Int Ed. 2011; 50:9672-9675.

20. Qian Y, Karpus J, Kabil O, Zhang SY, Zhu HL, Banerjee R, Zhao J, He C. Nat Commun. 2011; 2:495-501. [PubMed: 21988911]

21. Sasakura T, Hanaoka K, Shibuya N, Mikami Y, Kimura Y, Komatsu T, Ueno T, Terai T, Kimura H, Nagano T. J Am Chem Soc. 2011; 133:18003-18005. [PubMed: 21999237]

22. a) Lin VS, Chang CJ. Curr Opin Chem Biol. 2012; 16:595-601. [PubMed: 22921406] b) Xuan W, Sheng C, Cao Y, He W, Wang W. Angew Chem. 2012; 124:2325-2330.Angew Chem Int Ed. 2012; 51:2282-2284.c) Chan J, Dodani SC, Chang CJ. Nat Chem. 2012; 4:973-984. [PubMed: 23174976] d) Peng H, Chen W, Cheng Y, Hakuna L, Strongin R, Wang B. Sensors. 2012; 12:15907-15946. [PubMed: 23202239] e) Li X, Gao X, Shi W, Ma H. Chem Rev. 201310.1021/ cr300508p

23. a) Lin VS, Lippert AR, Chang CJ. Proc Natl Acad Sci USA. 2013; 110:7131-7135. [PubMed: 23589874] b) Liu J, Sun YQ, Zhang J, Yang T, Cao J, Zhang L, Guo W. Chem Eur J. 2013; 
19:4717-4722. [PubMed: 23460538] c) Liu T, Xu Z, Spring DR, Cui J. Org Lett. 2013; 15:23102313. [PubMed: 23614763] d) Wan Q, Song Y, Li Z, Gao X, Ma H. Chem Commun. 2013; 49:502-504.e) Liu C, Peng B, Li S, Park C, Whorton AR, Xian M. Org Lett. 2012; 14:2184-2187. [PubMed: 22486842]

24. a) Zheng H, Zhan X, Bian Q, Zhang X. Chem Commun. 2013; 49:429-447.b) Seo H, Jun ME, Egorova OA, Lee K, Kim KJ, Ahn KH. Org Lett. 2012; 14:5062-5065. [PubMed: 22998036] c) Urano Y, Kamiya M, Kanda K, Ueno T, Hirose K, Nagano T. J Am Chem Soc. 2005; 127:48884894. [PubMed: 15796553] d) Kawaguchi M, Okabe T, Okudaira S, Hanaoka K, Fujikawa Y, Terai T, Komatsu T, Kojima H, Aoki J, Nagano T. J Am Chem Soc. 2011; 133:12021-12030. [PubMed: 21721554] e) Li Z, Gao X, Shi W, Li X, Ma H. Chem Commun. 2013; 49:5859-5861.f) Chen W, Li Z, Shi W, Ma H. Chem Commun. 2012; 48:2809-2811.g) Zhang YY, Chen W, Feng D, Shi W, Li XH, Ma H. Analyst. 2012; 137:716-721. [PubMed: 22159212] h) Yuan L, Lin W, Xie Y, Chen B, Zhu S. J Am Chem Soc. 2012; 134:1305-1315. [PubMed: 22148503]

25. Guo Y, Yang X, Hakuna L, Barve A, Escobedo JO, Lowry M, Strongin RM. Sensors. 2012; 12:5940-5950. [PubMed: 22778623]

26. a) Li Z, Li X, Gao X, Zhang Y, Shi W, Ma H. Anal Chem. 2013; 85:3926-3932. [PubMed: 23506563] b) Chen W, Liu C, Peng B, Zhao Y, Pacheco A, Xian M. Chem Sci. 2013; 4:28922996. [PubMed: 23750317]

27. a) Zhao Y, Bhushan S, Yang C, Otsuka H, Stein JD, Pacheco A, Peng B, Devarie-Baez NO, Aguilar HC, Lefer DJ, Xian M. ACS Chem Biol. 2013; 8:1283-1290. [PubMed: 23547844] b) Zhao Y, Wang H, Xian M. J Am Chem Soc. 2011; 133:15-17. [PubMed: 21142018] c) DevarieBaez NO, Bagdon PE, Peng B, Zhao Y, Park C, Xian M. Org Lett. 2013; 15:2786-2789. [PubMed: 23697786] d) Park C, Zhao Y, Zhu Z, Pacheco A, Peng B, Devarie-Baez NO, Bagdon P, Zhang H, Xian M. Mol BioSyst. 2013; 9:2430-2434. [PubMed: 23917226] 


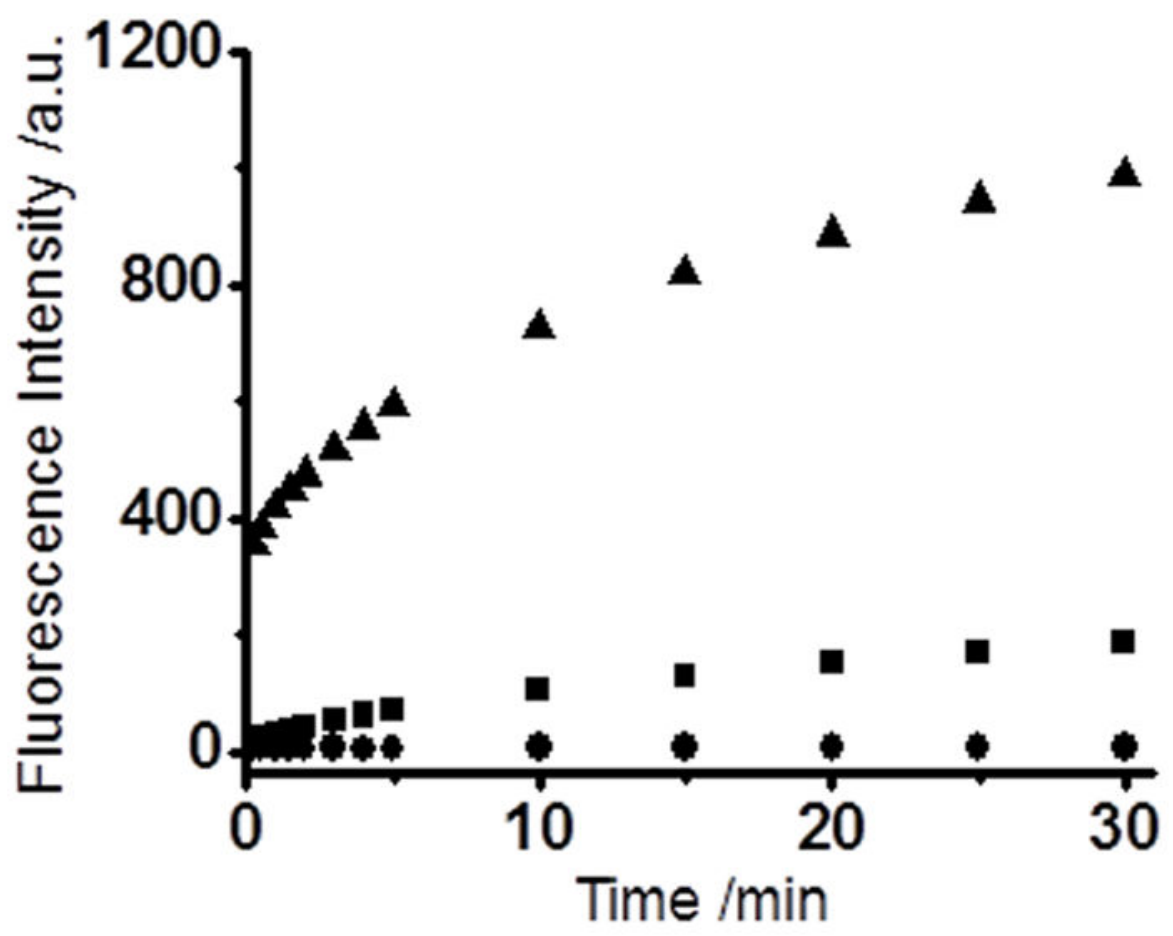

Figure 1.

Time-dependent fluorescence changes of $10 \mu \mathrm{M}$ WSP1 in the presence ( $\boldsymbol{\square}$ and $\boldsymbol{\Delta}$ ) or absence (O) of $50 \mu \mathrm{M}$ NaHS. (A) and (今) data were obtained in $10 \mathrm{mM}$ PBS buffer (pH 7.4) containing $1 \mathrm{mM} \mathrm{CTAB}$. (ם) data were obtained in $\mathrm{CH}_{3} \mathrm{CN} / \mathrm{PBS}$ buffer $(10 \mathrm{mM}, \mathrm{pH} 7.4$, 1:1, v/v). Data were acquired at $516 \mathrm{~nm}$ with excitation at $476 \mathrm{~nm}$. 


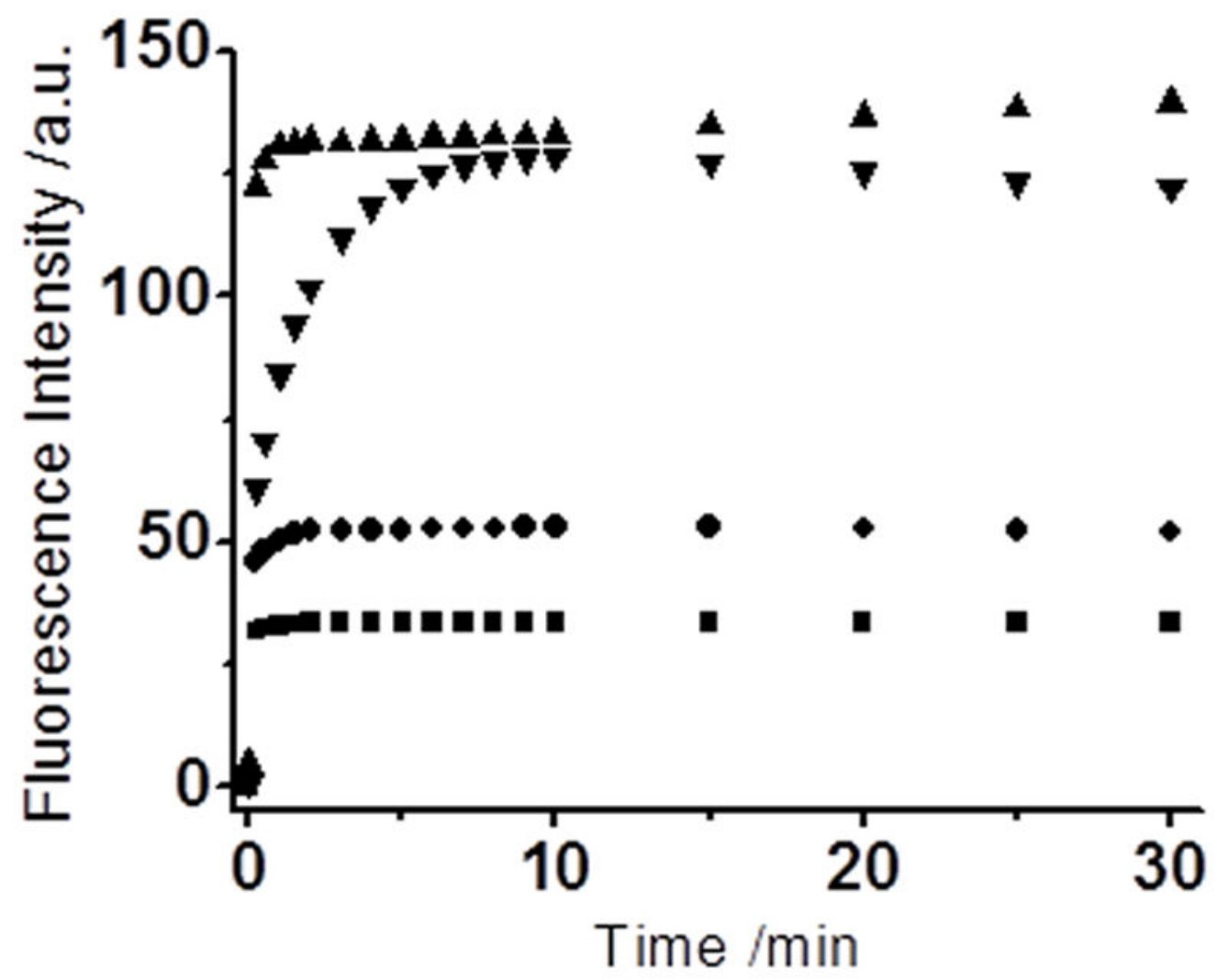

Figure 2.

Time-dependent fluorescence changes of the probes $(10 \mu \mathrm{M})$ in the presence of NaHS $(50$ $\mu \mathrm{M})$, The reactions were carried out for $30 \mathrm{~min}$ at room temperature in PBS buffer (10 $\mathrm{mM}$, $\mathrm{pH}$ 7.4) with $1 \mathrm{mM}$ CTAB. Data were acquired at $456 \mathrm{~nm}$ with excitation at $385 \mathrm{~nm}$ for WSP2 (ם); at $586 \mathrm{~nm}$ with excitation at $550 \mathrm{~nm}$ for $\mathbf{W S P 3}(\mathbf{O})$; at $531 \mathrm{~nm}$ with excitation at $512 \mathrm{~nm}$ for WSP4 (A); at $525 \mathrm{~nm}$ with excitation at $502 \mathrm{~nm}$ for WSP5 ( $\boldsymbol{\nabla})$. 

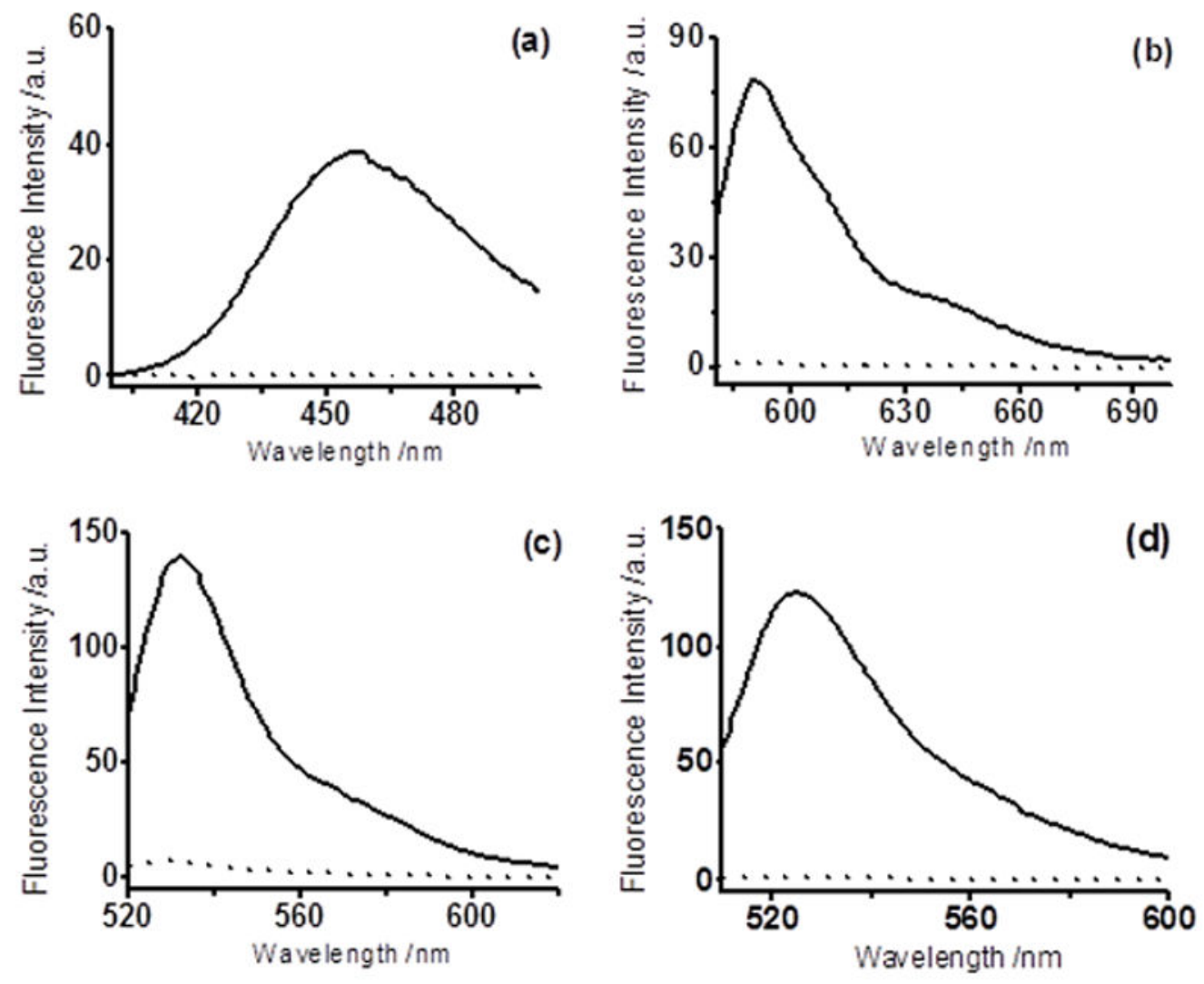

Figure 3.

Fluorescence spectra changes of probes $(10 \mu \mathrm{M})$ in the absence (dot line) or presence (solid line) of NaHS $(50 \mu \mathrm{M})$, The reactions were carried out for $5 \mathrm{~min}$ at room temperature in PBS buffer (10 mM, pH 7.4) with $1 \mathrm{mM} \mathrm{CTAB.} \mathrm{Data} \mathrm{were} \mathrm{acquired} \mathrm{with} \mathrm{excitation} \mathrm{at} 385$ $\mathrm{nm}$ for WSP2 (a); with excitation at $550 \mathrm{~nm}$ for WSP3 (b); with excitation at $512 \mathrm{~nm}$ for WSP4 (c); with excitation at $502 \mathrm{~nm}$ for WSP5 (d). 

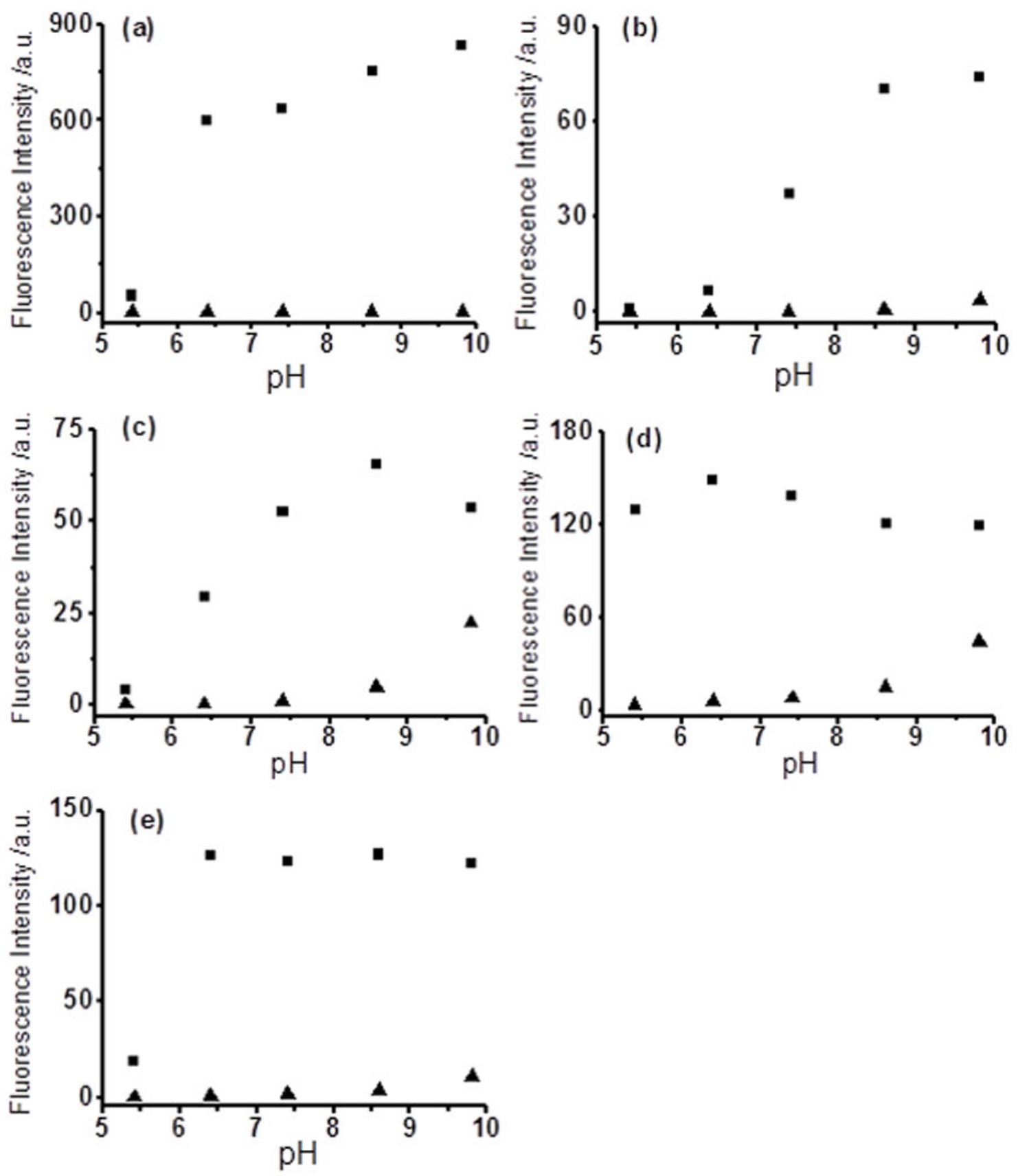

Figure 4.

Fluorescence intensity changes of the probes $(10 \mu \mathrm{M})$ at different $\mathrm{pH}$ values in the absence $(\Delta)$ or presence $(\mathbf{\square})$ of NaHS $(50 \mu \mathrm{M})$, The reactions were carried out for $5 \mathrm{~min}$ at room temperature in $10 \mathrm{mM}$ PBS solution with $1 \mathrm{mM} \mathrm{CTAB}$. WSP1 (a), WSP2 (b), WSP3 (c), WSP4 (d), and WSP5 (e). 

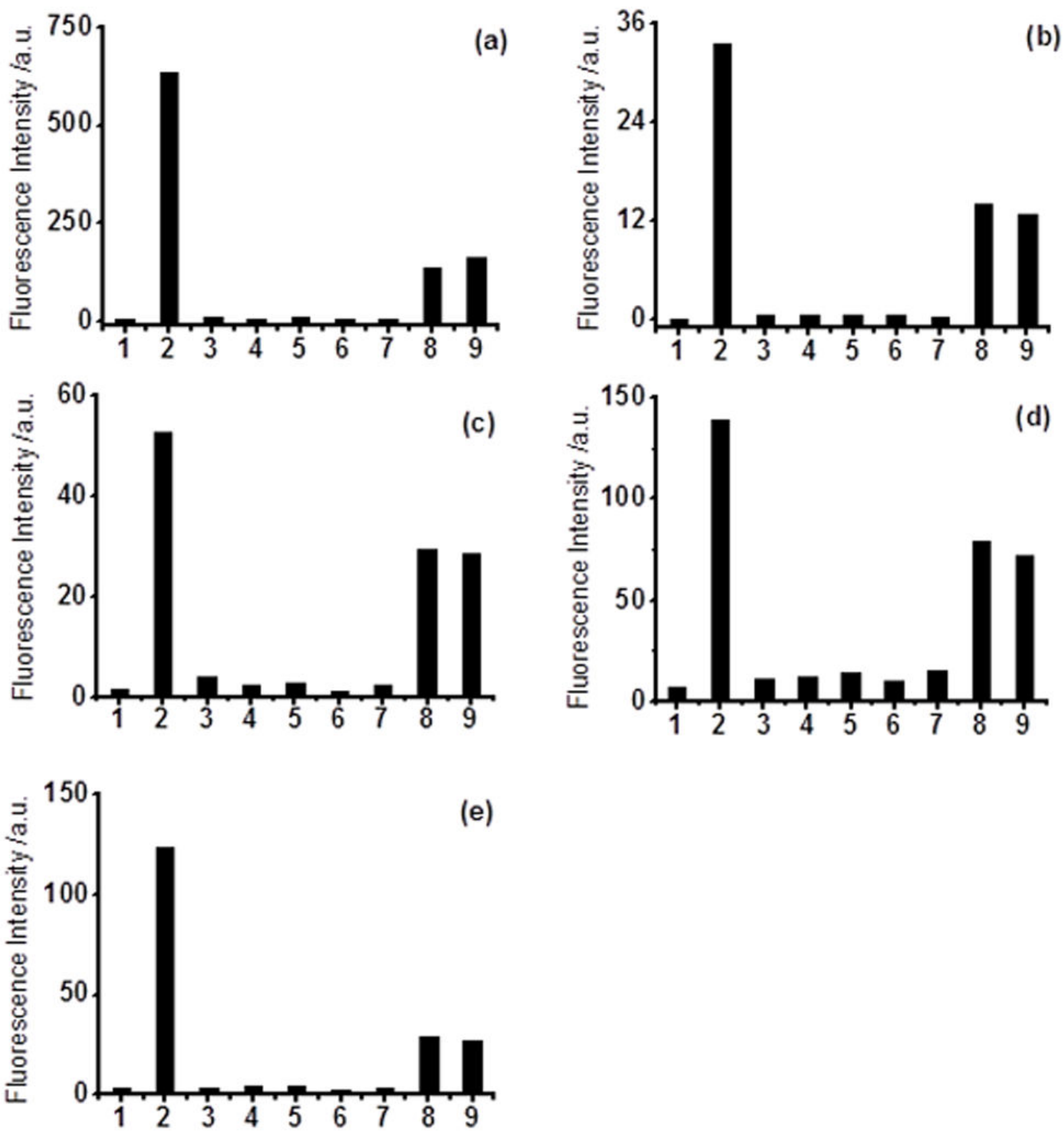

Figure 5.

Fluorescence intensity of the probes $(10 \mu \mathrm{M})$ in the presence of various reactive sulfur species: 1) control; 2) $50 \mu \mathrm{M}$ NaHS; 3) $200 \mu \mathrm{M}$ Cys; 4) $200 \mu \mathrm{M} \mathrm{GSH}$;) $200 \mu \mathrm{M} \mathrm{Hcy}$; 6) $200 \mu \mathrm{M} \mathrm{Na} \mathrm{SO}_{3}$; 7) $200 \mu \mathrm{M} \mathrm{Na} \mathrm{S}_{2} \mathrm{O}_{3}$; 8) $50 \mu \mathrm{M} \mathrm{NaHS}+200 \mu \mathrm{M}$ Cys; 9) $50 \mu \mathrm{M} \mathrm{NaHS}+$

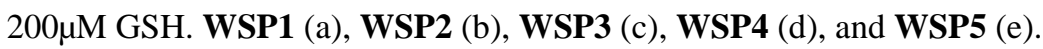



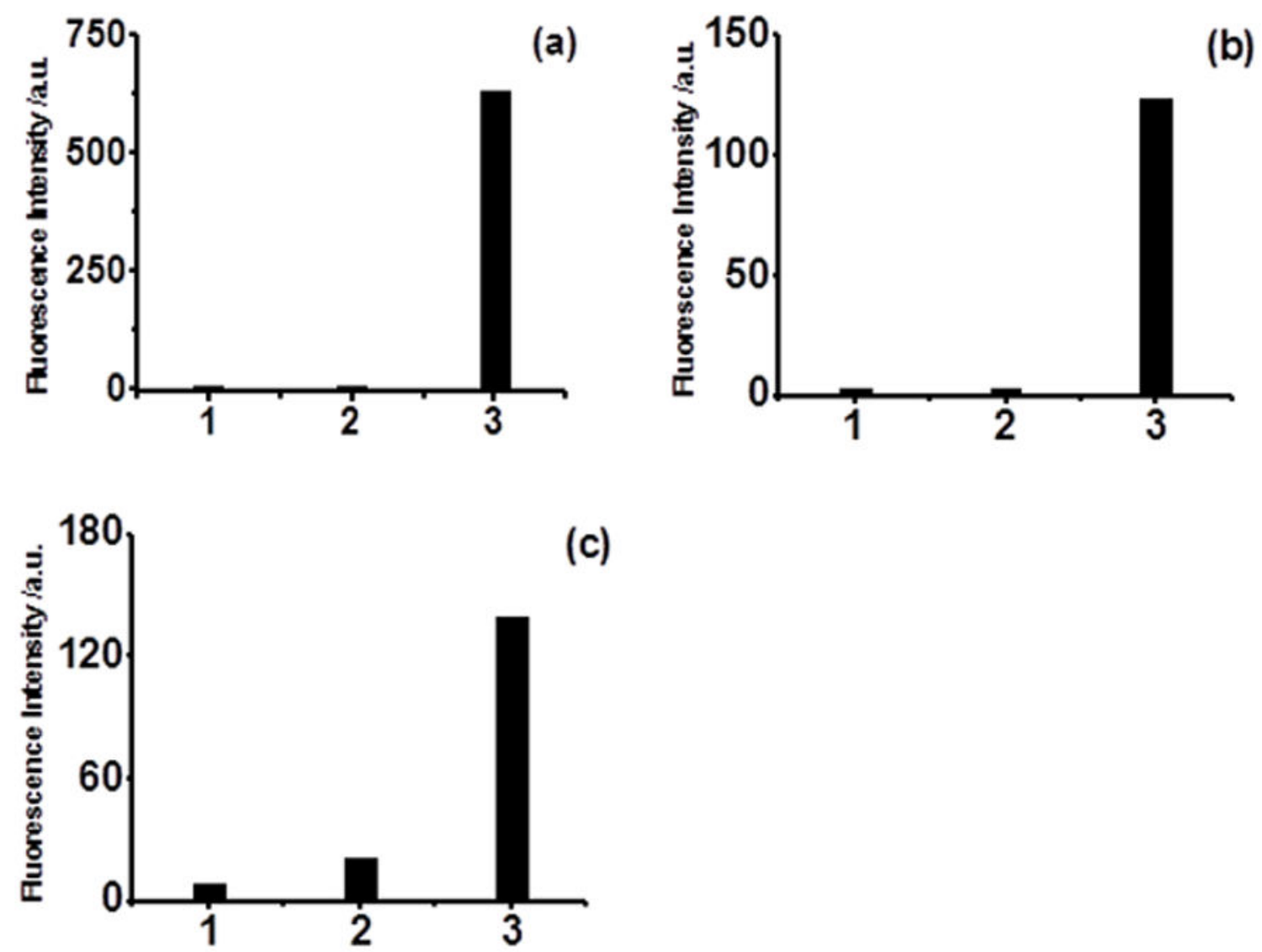

Figure 6.

Fluorescence intensity of the probe $(10 \mu \mathrm{M})$. 1) control, without the esterase; 2$)$ incubate with esterase $(0.06 \mathrm{U} / \mathrm{mL})$ at room temperature for $30 \mathrm{~min} ; 3)$ incubate with $50 \mu \mathrm{M} \mathrm{NaHS}$ for 5 min after 2). WSP1 (a), WSP4 (b), WSP5 (c). 

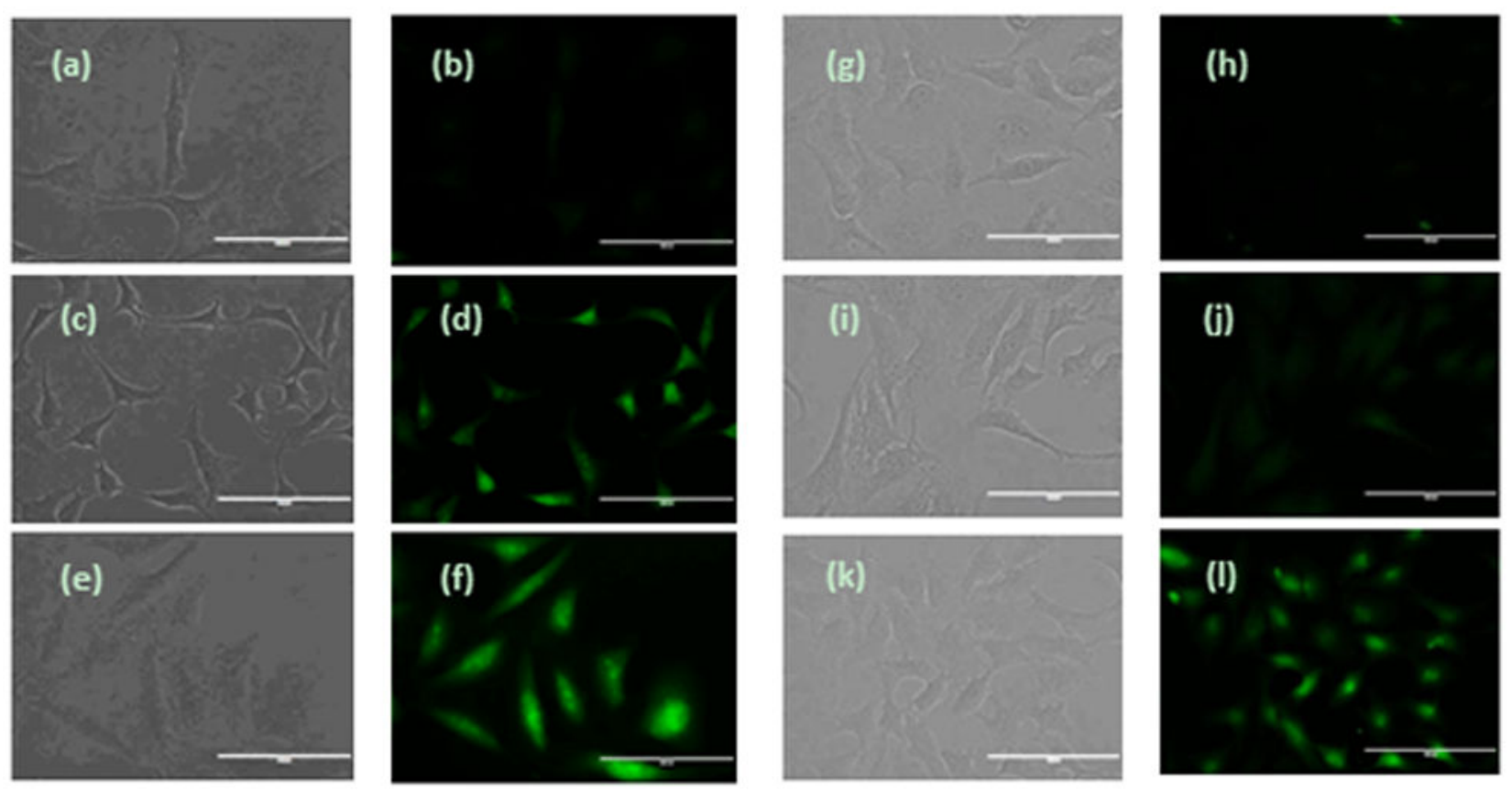

Figure 7.

Fluorescence images of $\mathrm{H}_{2} \mathrm{~S}$ in HeLa cells using WSP4 and WSP5. (a-f) Cells on 24-well plate were incubated with WSP4 $(30 \mu \mathrm{M})$ for $30 \mathrm{~min}$, then washed and subjected to different treatments. ( $\mathrm{a}$ and b) control (no NaHS was added); (c and d) treated with $30 \mu \mathrm{M} \mathrm{NaHS}$; (e and f) treated with $60 \mu \mathrm{M}$ NaHS. (g-l) Cells on 24-well plate were incubated with WSP5 (50 $\mu \mathrm{M}$ ) for $30 \mathrm{~min}$, then washed and subjected to different treatments. ( $\mathrm{g}$ and $\mathrm{h}$ ) control (no NaHS was added); (i and j) treated with $50 \mu \mathrm{M} \mathrm{NaHS;} \mathrm{(k} \mathrm{and} \mathrm{l)} \mathrm{treated} \mathrm{with} 100 \mu \mathrm{M}$ NaHS. (Scale bar: $100 \mathrm{~nm}$ ) 

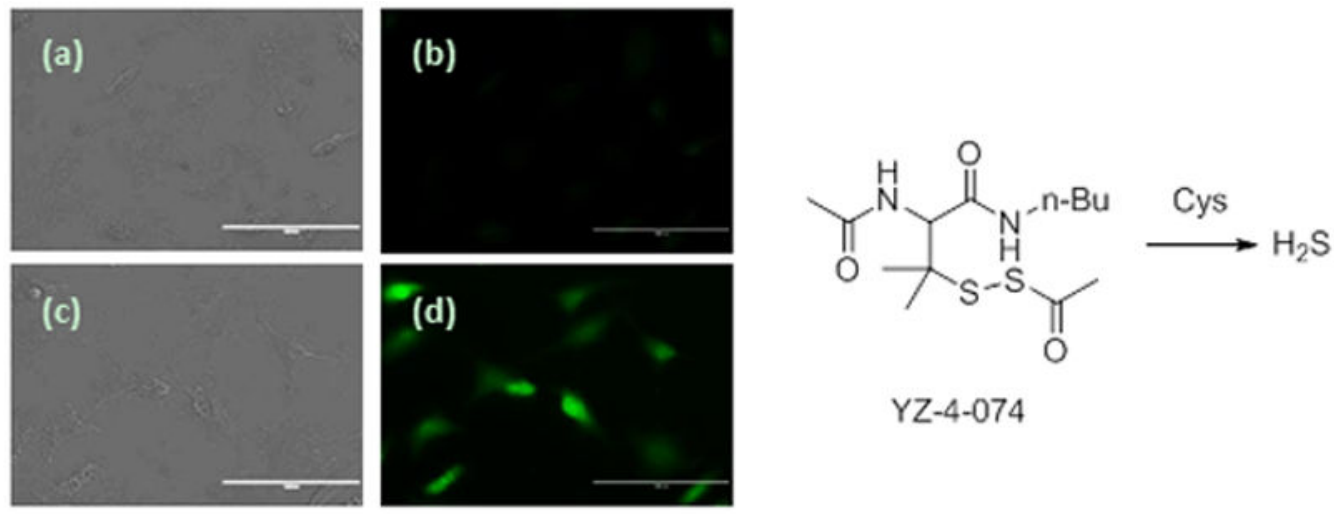

Figure 8.

Fluorescence images of $\mathrm{H}_{2} \mathrm{~S}$ production from a $\mathrm{H}_{2} \mathrm{~S}$ donor YZ-4-074 in HeLa cells. Cells on 24-well plate were incubated with or without YZ-4-074 for $30 \mathrm{~min}$, then washed and incubated with $30 \mu \mathrm{M}$ WSP4 for $30 \mathrm{~min}$. (a and b) controls (no donor was added); (c and d) treated with $100 \mu \mathrm{M}$ YZ-4-074. (Scale bar: $100 \mathrm{~nm}$ ) 


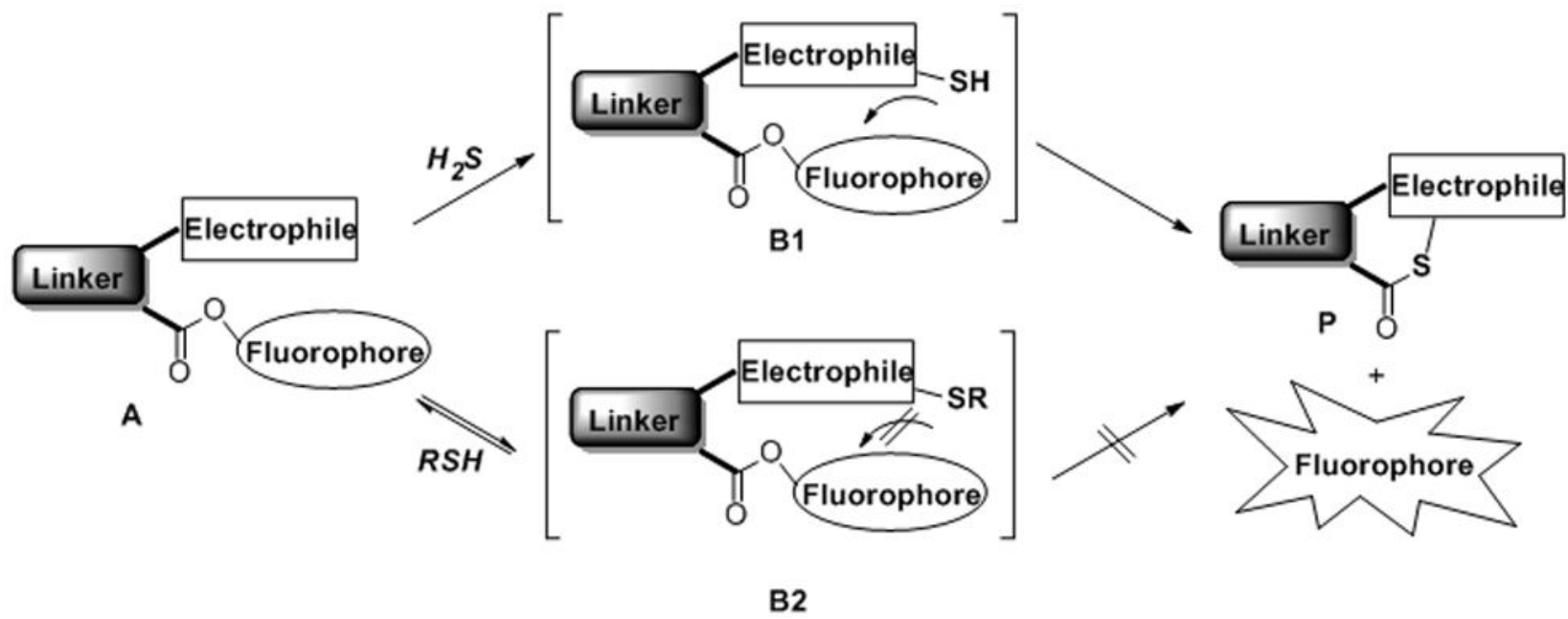

Scheme 1.

General design of the nucleophilic substitution-cyclization based fluorescent probes for $\mathrm{H}_{2} \mathrm{~S}$. 


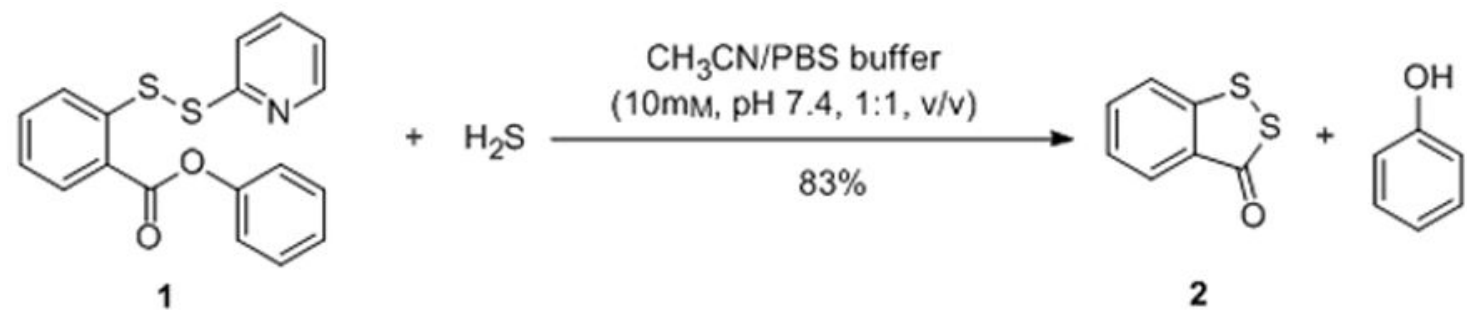

Scheme 2.

Model reaction between compound $\mathbf{1}$ and $\mathrm{H}_{2} \mathrm{~S}$. 


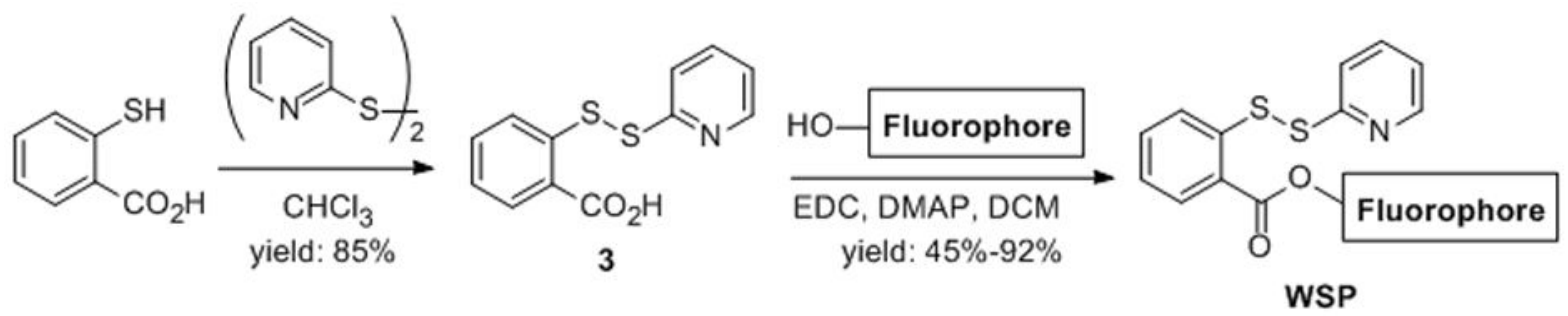<smiles>COc1ccc2c(c1)Oc1cc(OC(=O)c3ccccc3SSc3ccccn3)ccc1C21OC(=O)c2ccccc21</smiles><smiles>O=C(Oc1ccc2ccc(=O)oc2c1)c1ccccc1Sc1ccccn1</smiles>

WSP2<smiles>O=C1C=C=NC2=CC=C(OC(=O)c3ccccc3SSc3ccccn3)OC2=C1</smiles>

WSP3<smiles>Cc1ccccc1-c1c2ccc(=O)cc-2oc2cc(OC(=O)c3ccccc3SSc3ccccn3)ccc12</smiles><smiles></smiles>

Scheme 3.

Preparation of fluorescent probes WSP1-5. 


\section{Table 1}

Fluorescent properties of probes WSP1-5.

\begin{tabular}{llll}
\hline Probes & $\lambda_{\text {ex }}(\mathbf{n m})$ & $\lambda_{\text {em }}(\mathbf{n m})^{[a]}$ & $\Phi_{\mathbf{f}}^{[b]}$ \\
\hline WSP1 & 476 & 516 & 0.003 \\
WSP2 & 385 & 456 & 0.003 \\
WSP3 & 550 & 586 & 0.014 \\
WSP4 & 512 & 531 & 0.088 \\
WSP5 & 502 & 525 & 0.020 \\
\hline Ta] maximal emission of the probes. \\
Tb] The fluorescence quantum yield.
\end{tabular}




\section{Table 2}

Turn-on fold changes and detection limits (DL) of probes WSP1-5.

\begin{tabular}{lll}
\hline Probes & Turn-on folds & DL $^{[a]} / \mathbf{n M}$ \\
\hline WSP1 & 130 & 60 \\
WSP2 & 275 & 79 \\
WSP3 & 68 & 47 \\
WSP4 & 20 & 266 \\
WSP5 & 60 & 47 \\
\hline
\end{tabular}

${ }^{[a]} \mathrm{DL}$ is the detection limit (3S/m, in which $S$ is the standard deviation of blank measurements, $n=11$, and $m$ is the slope of the linear equation). [26] 